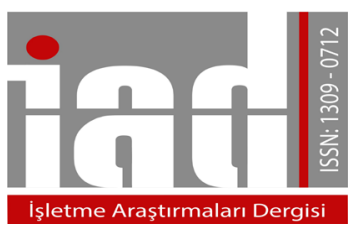

\author{
İşletme Araştırmaları Dergisi \\ Journal of Business Research-Turk \\ 10/4 (2018) 953-973
}

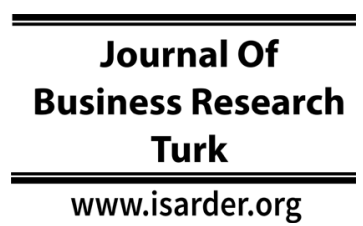

Research Article

\title{
Application of Activity Based Costing in Reverse Logistics Environment: A Case of End-of-life Vehicle Recovery in Turkey
}

\author{
Semra AKSOYLU \\ Kayseri University \\ Faculty of Applied Sciences \\ Department of Accounting and Financial \\ Management, Kayseri, Turkey \\ orcid.org/0000-0002-5837-1600 \\ aksoylus@erciyes.edu.tr
}

\author{
Neslihan DEMİREL \\ Kayseri University \\ Faculty of Applied Sciences \\ Department of International Trade and \\ Logistics, Kayseri, Turkey \\ orcid.org/0000-0002-9737-6666 \\ ndemirel@erciyes.edu.tr
}

\begin{abstract}
Nowadays, there has been a growing interest in reverse logistics in both theory and practice due to legislations, economic and ecological benefits, and social responsibilities. If enterprises incorporating reverse logistics activities to its structure want to realize the required level of customer service and comply with related obligations at the lowest total cost, analyzing the actualized reverse logistics activities and correct determination and reduction of costs of these activities are essential for them. Traditional accounting methods are inadequate for accurate assignment of overhead costs. In this paper, an actual application of Activity Based Costing (ABC) to reverse logistics activities is presented in order to help managers to improve their understanding of costs that arises from reverse logistics activities. An illustrative case study in the end-of-life vehicle (ELV) recovery industry in Turkey is presented to demonstrate the steps of how ABC is applied to reverse logistics systems. The results enable to efficient management of reverse logistics activities and their costs in an ELV recovery chain and exhibit which reverse logistics activities performed by a dismantler cause the highest cost and can be improved. In the case study, products (ELVs) are evaluated as inputs and the obtained materials from reverse logistics activities are evaluated as outputs of the system by force of the nature of reverse logistics. Results show that while most cost of the company $(52.7 \%)$ was related with the output of $\mathrm{B}$ Group of components/parts (sent to shredders); the minimum cost $(12.3 \%)$ was realized for the output of A Group components/parts (sent to recyclers). The remaining 35\% of the costs belong to the C Group of outputs (sent to secondary markets).
\end{abstract}

Keywords: Logistics Cost Management; Reverse logistics; Activity Based Costing (ABC); End-of-life Vehicle (ELV).

Received 29 October 2018; Received in revised from 15 December 2018; Accepted 20 December 2018 


\section{Introduction}

Globalization, technologic and economic developments and the shortening product life cycles have led to changes in business operations. New conditions have caused an increase in the importance of some activities other than production. One of the most important of these activities is logistics. Logistics activities are considered as a part of the supply chain and facilitate the flow of a product or service from the point of origin to the point of consumption. Main logistics activities can be listed as transportation, warehousing, information management, inventory management, procurement, demand forecasting, material handling, packaging, production planning, facility location, customer service, insurance, and customs clearance. Logistics costs involve all costs arising from these logistics activities. Identification of true costs of logistics operations and management of these costs are being more important day by day for businesses in terms of profitability, pricing decisions, and financial performance. On the other hand, firms recently incorporate reverse applications to their constitution to get remaining value of end-of-life (EOL) products, complying with obligations by governments and/or meeting the expectation of environmentally conscious customers. So, it is also very important to set the costs accurately for enterprises that incorporate reverse logistics applications to their systems. If enterprises that perform reverse logistics activities want to realize the required level of customer service and comply with obligations at the lowest total cost, it is fundamental to analyze the actualized reverse logistics activities and the costs of these activities. Since it is almost impossible to reduce the costs without sacrificing quality or to obtain higher quality while undergoing the same costs with competitors in today's business world, firms should focus on ways to eliminate both non-value added production and logistics activities to meet customer demands of lower priced and higher qualified products and services. Activity Based Costing (ABC) is a valuable tool at this point to obtain more precise information about value-added and non-value-added costs by the identification of cost drivers (Hilton 2005). Thus, ABC is of benefit to firms in terms of reducing the resources allocated to particular activities or increasing the productivity of these activities (Goldsby and Closs 2000). In this method, costs are activity-based allocated to cost items (products). Resource costs are turned into activity costs regarding the resources that are used by the activities, and then activity costs are turned into product costs regarding the activities that are used by the products (Özdemir and Kaygusuz 2009). An important point that both logistics with environmental consideration and $\mathrm{ABC}$ concepts intersect is the reduction of waste. Reverse logistics aims to reduce the amount of waste buried in landfills by recovering the returned products and also reduce the energy consumption, labor force and consequently costs by using treated materials/components in production process. ABC evaluates non-value added activities as waste as well and aims to increase the efficiency of the system by eliminating them as much as possible.

In this paper, we aim to show how $\mathrm{ABC}$ method can be implemented in reverse logistics environment to determine the costs that arising from the reverse logistics activities more precisely and to help managers to improve their decision making and management processes through accurate costing information. The rest of this paper is organized as follows: Section 2 presents the literature review regarding the use of $A B C$ as a tool for determining true costs of traditional forward logistics and reverse logistics activities. Section 3 presents the implementation of $\mathrm{ABC}$ in reverse logistics 
environment. A real case in end-of-life vehicle (ELV) recovery sector in Turkey is given in section 3.1 and the results are discussed in section 3.2. Finally, section 4 concludes the study.

\section{Literature Survey}

Many firms are realizing that value to a customer can be created through logistics management (Rajeshkumar and RameshBabu 2006). Lower level of customer services is inevitable if a firm cannot achieve the same level of quality in its logistics activities, independently how much qualified products it produces. On the other hand, superior qualified logistics activities cause increased logistics costs which affect the product or service prices negatively. In today's competitive market, firms have an increasing need to concentrate on logistics costs depending on the importance of customer service in a company's strategy (Krajnc et al. 2012). ABC method provides a beneficial tool to determine the costs accurately and manage them efficiently. There are a significant number of studies in the literature that integrates the $\mathrm{ABC}$ method with logistics management and highlights the benefits of using $\mathrm{ABC}$ such as improved performance, processes, productivity, profitability, and visibility of costs. However, the survey of the literature dealing with $\mathrm{ABC}$ along with logistics management leads to the conclusion that the lack of studies that examining the detailed adoption of $\mathrm{ABC}$ on logistics costs of a firm in a supply chain or whole supply chain as mentioned in (Brierley et al. 2006; AlOmiri and Drury 2007; Askarany et al. 2010). Some studies in the literature have addressed $\mathrm{ABC}$ and logistics together in terms of a member of the supply chain, a decision or part of it while others perform $\mathrm{ABC}$ for managing the overall supply chain costs.

Studies that researched $\mathrm{ABC}$ method in relation to logistics in the literature are given below: Pirttilla and Hautaniemi (1995) and Arslan and Varol (2010) proposed a framework to exhibit how $\mathrm{ABC}$ principles could be applied to other company functions except for production. They applied ABC approach for distribution and warehousing management as important activities of logistics. LaLonde and Pohlen (1996) compared the available tools for effectively costing an extended supply chain and aimed to determine the most effective costing method to improve the competitiveness and profitability. Authors claimed that $\mathrm{ABC}$ is a potential tool for both evaluating the overall supply chain performance and the individual performance of the members of supply chain. Dekker and van Goor (2000) studied the role of accounting information in Supply Chain Management (SCM) and provided a case in the pharmaceutical industry based on $\mathrm{ABC}$ modeling in order to observe the consequences of changes of activities which are carried out in the supply chain. Lin et al. (2001) presented the stages of the implementation of ABC to SCM in order to help managers to understand the logistics activities and costs and their effects on corporate decision making. Seuring (2002) presented a framework for supply chain costing with ABC in three steps. Stapleton et al. (2004) emphasized that traditional costing systems don't provide accurate cost information and $\mathrm{ABC}$ is a suitable tool for costing and measuring the performance of logistics processing. Authors claimed that $\mathrm{ABC}$ is an opportunity to help logistics managers having adequate control over their costs. They aimed to show how $\mathrm{ABC}$ can be used as a tool for determining the costs correctly in logistics and marketing practices in their study. Pohlen and Coleman (2005) combined the economic value added analysis (EVA) with $\mathrm{ABC}$ to analyze the financial and nonfinancial effects of the operational decisions on an individual basis and on supply chain 
basis. Baykasoğlu and Kaplanoğlu (2008) proposed an ABC approach for a land transportation company with the aim of determining and evaluating the true costs of its operations and services. Tsai (2009) implemented fuzzy goal programming approach for supplier selection in a green supply chain. An integrated ABC and value-chain structure is used to recover cost and performance of suppliers. Askarany et al. (2010) researched the integration of $\mathrm{ABC}$ approach in the SCM issues in the organizations operating in New Zealand through using a survey questionnaire. Authors deduced that small businesses compared to large businesses independent from the sector and nonmanufacturing businesses to manufacturing businesses need more attention to proceed with a higher level of adoption of ABC. In a later study by Askarany and Yazdifar (2012), authors also conducted a survey to determine the relationship between the reported adoption rates for $\mathrm{ABC}$ and the diffusion process approaches (the stages model/the levels model) chosen to measure its adoption rates to participants from Australia, New Zeland and the UK. Şen (2014) investigated the logistics costs in detail and examined and compared the different methods in which one of them is that ABC used for controlling and management of logistics costs. Wang et al. (2010) reported the situation of a Chinese consumer food production firm that using $\mathrm{ABC}$ to increase its competitive advantage. Another study dealing with a firm's logistics costs with the aid of ABC is done by Krajnc et al. (2012). They proposed a model of ABC of logistics costs in a Slovenian paper manufacturing company. Schulze et al. (2012) developed a conceptual framework for $\mathrm{ABC}$ in a supply chain environment and proposed a case study in order to assess the applicability of the proposed model.

Another challenge faced by enterprises is that taking responsibility of reverse flows of their products. Chileshe et al. (2016) investigated the reverse logistics drivers given in literature and explored if they are all valid for construction industry and how they change. They implemented interviews with eight practitioners and analyzed the results. They classified the drivers into 4 main categories as economical, social, environmental, and targeted demand by an exclusive clientele. In an another study, Chileshe et al. (2016) performed questionnaire and interviews to South Australia practitioners in order to identify the practices that could promote the adoption of reverse logistics activities in construction industry which is specified a new and rarely studied domain of reverse logistics in the study. Peretti et al. (2015) analyzed the challenges and opportunities of the implementation of reverse logistics in humanitarian logistics. Hao et al. (2018) proposed a combined model consisting of a grey model, exponential smoothing and an artificial neural network for predicting the number of recycled ELVs. Lin et al. (2018) proposed a facility location allocation problem for ELV recycling network and formulated it as a mathematical model. They solved the problem by a novel approach based on artificial bee colony. Another study handling locationallocation problem for ELV recycling network is proposed by Zhongdong et al. (2018). Authors considered carbon emissions costs with fixed costs of facilities and transportation costs in the objective function. If enterprises want to decrease the costs arising from the reverse logistics activities, they must analyze these activities and make good selections in these activities (Khan et al. 2017). There are only a few studies in the literature using $\mathrm{ABC}$ for precise cost analyzing and management of reverse logistics activities. Bras and Emblemsvag (1995) dealt with developing an ABC model for product design under uncertainty environment. Authors focused on design for demanufacturing as the area of application. Goldsby and Closs (2000) presented the application of $\mathrm{ABC}$ to reverse logistics activities and illustrated it on a case study of a 
Michigan beverage distributor and retailer collecting the empty containers with the purpose of recycling. Authors focused on the costs of retailers and distributors arising from collection, processing and administration activities of returnable beverage containers. Coates and Rahimifard (2008) proposed a cost modeling approach for ELVs in UK vehicle recovery sector regarding the ELV recycling legislation. Authors aimed to help operators to understand the detailed costs and revenues presented within the vehicle recovery chain and improve the value of ELV. Tsai and Hung (2009) proposed a two-stage multi-objective decision framework integrated with $\mathrm{ABC}$ for treating and recycling the waste electrical and electronic equipment (WEEE) to obtain more precise and efficient solution. Khan et al. (2017) also dealt with $\mathrm{ABC}$ in the reverse logistics environment for electronic equipments. They proposed a conceptual decision-making model for identifying the best alternative for recovering the products with different options (reconditioning, remanufacturing, reselling, recycling, maintenance and disposal) and defining the relevant cost factors. They classified the reverse logistics activities for electronic product recycling as collection, classification, transportation, and warehousing and the returned products as high, good, medium qualified and scraps.

Although it is understandable from the literature that $\mathrm{ABC}$ is a well technique for costing and measuring the performance of logistics processing as also mentioned in Stapleton et al. 2004, the decision framework about integrated costing and performance evaluation with reverse logistics has not been well developed so far in the literature. Given studies above regarding $\mathrm{ABC}$ in reverse logistics environment constitute a conceptual framework for using $\mathrm{ABC}$ method to determine reverse logistics costs precisely. These studies emphasize the potential of such a framework about tracking and managing the reverse logistics costs. However, they don't propose a comprehensive case dealing with the application of ABC method to a firm's costs performing reverse logistics activities The contributions of this paper are as follows: (i) to represent the usability of $\mathrm{ABC}$ as a tool for determining the reverse logistics costs (ii) to perform the phases of $\mathrm{ABC}$ method comprehensively, (iii) to propose a case including the adoption of $\mathrm{ABC}$ in reverse logistics environment, (iv) to consider ELV as a returned product for which OEMs are responsible in many countries in terms of recovery of large percentage of weights, (v) to consider ELV directive 2000/53/EC as reference in order to standardize the reverse logistics activities performed in facility with other facilities and enable to use of the approach in other firms. The approach performed in this paper can be applied to other sectors and processes in reverse logistics environment which is not limited to ELV recycling.

\section{ABC in Reverse Logistics Environment}

Legislation within the European Community gives high importance to recycled products (Shibi and Eglese 2009) and it has established the responsibility for the EOL products to the manufacturers in several industries such as automotive, battery, packaging material, electrical and electronic equipment, and tire. Reverse logistics, can be defined as a process that includes all logistics activities and starts from the point of consumer to transform the used products to products which are reusable in the market (Demirel and Gökçen 2008). Firms incorporating reverse logistics activities to their constitution can improve customer service levels, reduce production costs, and provide a green image (Demirel and Gökçen 2008). 
Firms seeking to benefit from the economic value of returned products, to achieve the targets obliged with legislations, and to maintain and/or increase its market share by gaining a green image should understand, determine and manage its reverse logistics costs truly. Through calculations of reverse logistics costs with ABC, firms not only can achieve these goals with minimum costs, but also can identify performance indicators and then assess the performance of relevant departments and employees and can also take relevant measures to improve productivity if needed. In $\mathrm{ABC}$, since activities are seen as the main reason for costs; initially business activities that enable production are analyzed finically which allows the elimination of non-value added ones and aggregation of similar ones (Chen 1996). ABC is used for accurate allocation of relevant costs to items. In practice, apart from directly attributable costs, all activities have common costs and these costs should also be allocated to the activities. The difference of $\mathrm{ABC}$ from the traditional costing arises at this point. $\mathrm{ABC}$ has emerged to obtain more precise cost information of products and services by means of allocating these indirect costs truly to the finished products and services. Indirect costs are allocated to products and services based on the activities required to produce them in a two phase manner instead of using single volume cost driver (Baykasoğlu and Kaplanoğlu, 2008). General implementation steps of ABC are presented in Figure 1.

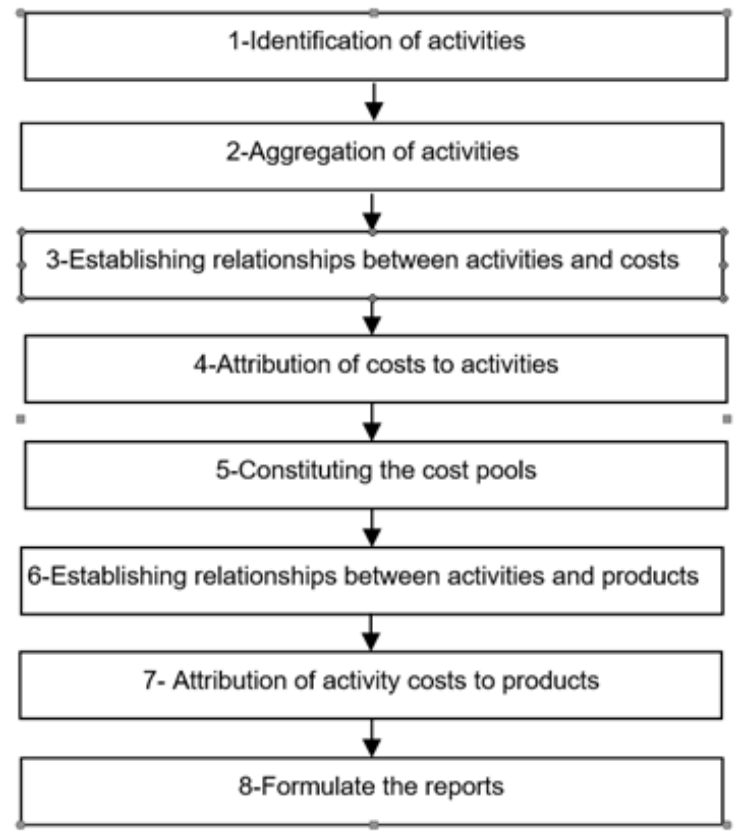

Figure 1. Steps of ABC approach

Automotive industry is one of the sectors that the responsibilities of manufacturers are determined by regulations in many developed and developing countries, particularly in those who are a member of the European Union (EU). Both regulations about controlling of ELVs in Turkey and EU (2000/53/EC) aims at limiting the use of hazardous substances in vehicles as well as obligating the reusing, recycling and recovery rates of ELVs over specified targets. In section 3.1, in order to present the implementation of $\mathrm{ABC}$ as a tool to calculate the costs of reverse logistics activities accurately, we present a conceptual framework to exhibit how $\mathrm{ABC}$ principles can be applied to a dismantler's functions locating in an ELV recovery supply chain. 


\subsection{ELV Dismantling Case}

ELVs must only be treated at permitted treatment facilities which are known as Authorized Treatment Facilities (ATFs) and have to meet strict environmental standards in Turkey. ATFs are licensed and regulated by the Turkish Republic Ministry of Environment and Urbanization. Since manufacturers are responsible for free take-back of ELVs from end-users as well as depolluting, dismantling, shredding and recycling of them, it is necessary to manage the ELV recovery process effectively to minimize the costs (Demirel et al. 2016). ELVs undergo a process of depollution, involving the removal of fuel, oil and other fluids, as well as the battery, airbags and heavy metals at dismantlers (Demirel et al. 2016). There are 105 licensed dismantlers existing in Turkey and 5 of them are operating in Kayseri (Turkish Republic Ministry of Environment and Urbanization, 2018). The proposed general framework is justified by a real case performed in Kayseri which is one of the big cities of Turkey and located in Central Anatolia Region. In practice, monthly data of the firm is taken into consideration and calculations are made for that time interval. Monthly recycling amount of the regarding facility is 275 ELVs. We use the term of "output" instead of "product" in the rest of the paper in order to prevent the confusion since the raw materials that enters to firm for dismantling are actually returned products (ELVs), and the finished products are the components/ parts or materials of ELVs obtained from activities performed in dismantler due to the nature of reverse logistics processes. The used percentages of materials and components in a typical ELV are given in Figure 2 for 2015 ELV compositions (GHK, 2006). We categorized the components of an ELV that are outputs of a dismantler into three groups as mentioned in the following paragraph. At dismantlers, fluids are drained and disassembly operation is performed. The fuel, the engine oil, the transmission oil, the hydraulic oil, the coolant, the air conditioner fluid, the brake fluid and the steering fluid are drained from the ELVs. While some components are sent to the recyclers, remaining ELV body which is called as 'hulk' is sent to the shredders. In addition, reusable parts such as the engine, the differential, the transmission, body panels (e.g., the hood, the doors and the bumpers) and the tire are sold back to secondary markets (Özceylan et al. 2017).

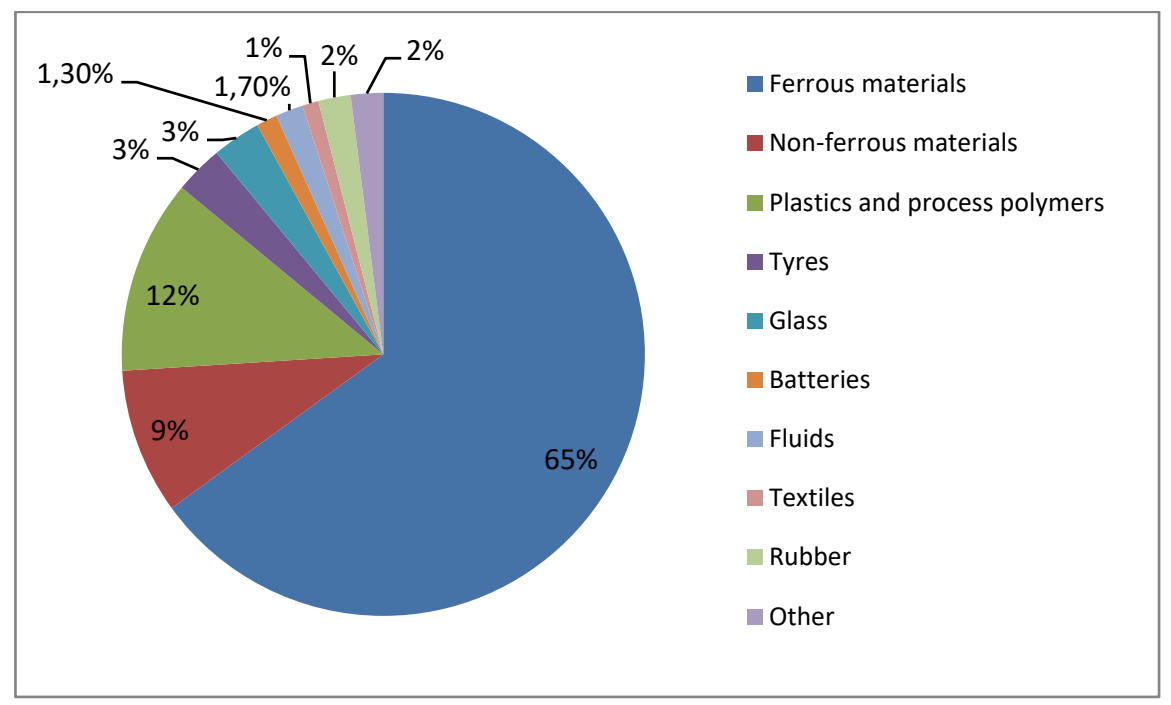

Figure 2. Composition of an ELV (2015) 
The outputs of a dismantler are classified under three groups as an assumption of study for simplicity: (1) The outputs to be sent to the recycling facility (Group A), (2) The outputs to be sent to the shredder (Group B), (3) The outputs to be sent to the secondary market (Group C). Considering the relationships between the above specified outputs and cost items, since the manufacturers have to take back the ELVs from the owners free of charge according to regulations, it is assumed that they did not pay or charge for ELVs. Therefore, direct raw material cost is not considered. For the second cost item "Direct Labor Cost", a direct connection should be established between outputs and labor costs. Such a direct connection is determined only between the C Group output to be sent to the secondary market and the testing and bar-coding activity. An individual employee in the facility performs only testing and bar-coding activity and his cost to facility is $2.500 \mathrm{TL}(1 \$=4.8 \mathrm{TL})$. A direct connection is not established between the other labor costs and outputs; such costs are then allocated as indirect costs and regarded as general production costs. The third cost item "General Production Costs" is composed of production-related cost items subjected to allocation.

\subsection{Implementation and Results}

The first step in ABC approach (given in Figure 1) is the identification and description of the activities. The activities performed in a dismantler are provided below by observation and taking the relevant regulations into consideration (Directive 2000/53/EC, Depolluting End-of-Life Vehicles, Xia et al. 2016):

- ELV acceptance and deregistration (this activity incorporates the following operations (Liu 2006; Xia et al. 2016): weighting and numbering of ELV, importing and saving the main information including the owner, identification number, license number, brand and type, body color, weight, engine number, vehicle identification number or frame number, fabrication date, and acquisition date, license retrieval, ELV inspection, designation

- Inspection and designation

- Warehousing

- Depollution (This activity includes the following operations:

- Checking the IDIS information system,

- Disconnection of battery and removal of batteries and liquefied gas tanks,

- Removal of wheels and tires and balancing weights,

- Placing the vehicle on the lift providing above \& below movement for the removal of fluids and gases,

- Removal and separate collection and storage of fuel, motor oil, transmission oil, gearbox oil, hydraulic oil, cooling liquids, antifreeze, brake fluids, airconditioning system fluids and any other fluid contained in the ELV,

- Removal, as far as possible, of all components identified as containing mercury,

- Removal of catalyst, oil filter, and any items marked as hazardous)

- Dismantling of reusable/remanufacturable parts and components

- Taking the vehicle on concrete pad from the lift

- Removal or neutralization of potential explosive components, (e.g. air bags),

- Testing and bar-coding

- Crushing

- Transportation 
In the second step, the activities with a common source items are aggregated to alleviate calculation load without moving away from accurate calculation and activities are more generally defined. Through taking the order of operation into consideration, activities were integrated as follows (Figure 3): (1) ELV acceptance and deregistration (including the deregistration, inspection and designation of ELV operations); (2) Warehousing (including the storage of ELVs and outputs); (3) Depollution (including the IDIS information system checking, disconnection of battery and removal of batteries and liquefied gas tanks, removal of wheels and tires and balancing weights, placing the vehicle on the lift, removal and separate collection and storage of fluids, removal of all components identified as containing mercury, removal of catalyst, oil filter, and any items marked as hazardous); (4) Dismantling (including the dismantling of reusable/remanufacturable parts and components, taking the vehicle on concrete pad from the lift, removal or neutralization of potential explosive components); (5) Testing and bar-coding; (6) Crushing; (7) Transportation.
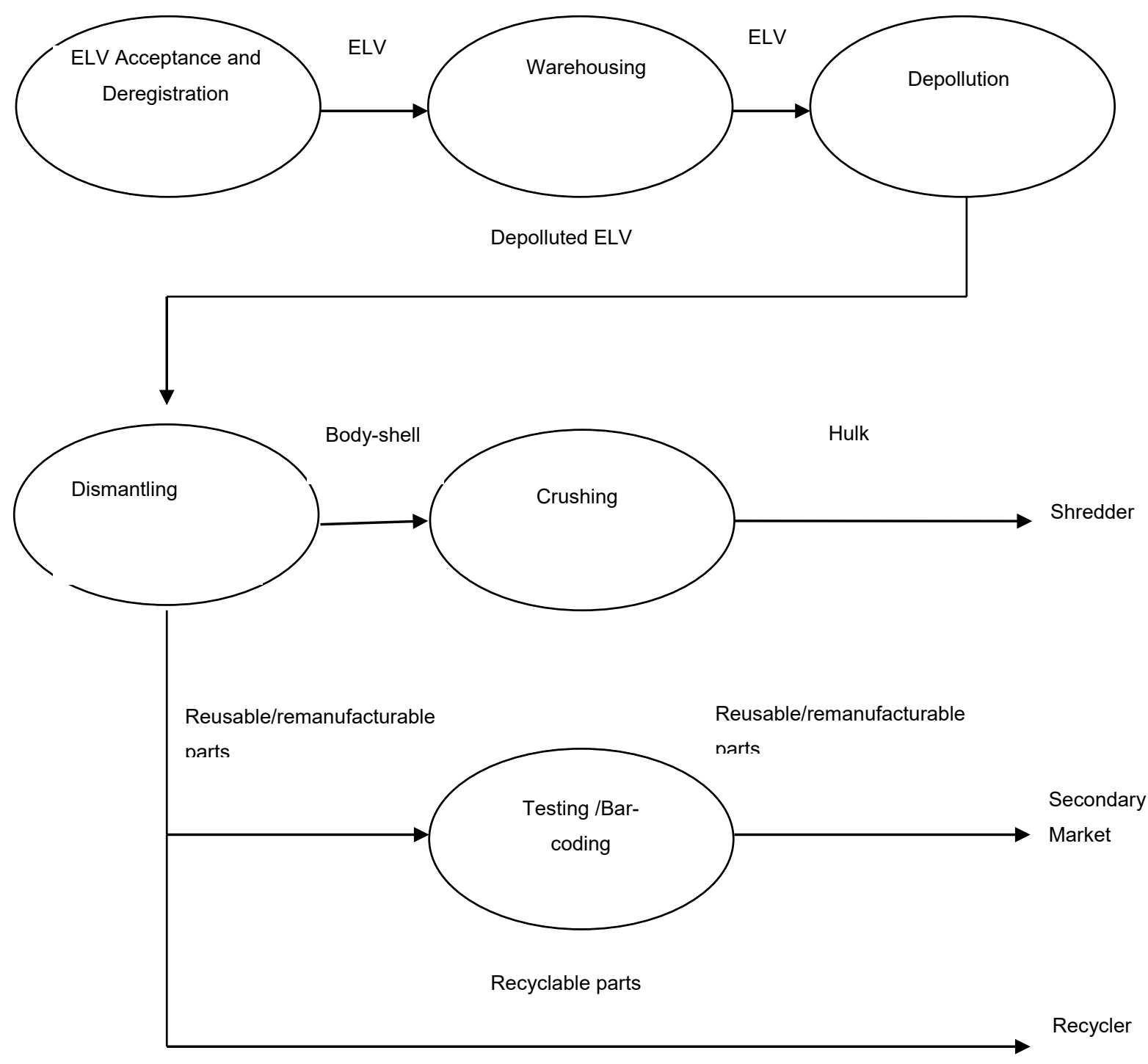

Figure 3. ELV treatment activities performed in a dismantler 
In the third step, the relationships between the activities and the costs to be allocated are established and cost drivers are identified. The costs directly attributable to the activities are not subjected to allocation. Costs of a dismantler that are subjected and not-subjected to allocation are identified below:

\section{The costs not subjected to allocation;}

Of the above-mentioned activities, since testing and bar-coding activities are directly related with the output, the costs associated with these activities are assumed to be direct labor cost of the output to be sent to secondary market (Group C) and they are considered as directly attributable and not incorporated to allocation. An employee is working for ELV acceptance and deregistration and the cost of that staff to the facility is 2.500 TL. There is a computer, printer and some fixtures in ELV reception office. Monthly depreciation expense of these assets is $120 \mathrm{TL}$. Then, the total cost attributable to ELV acceptance and deregistration activity is 2.620 TL. All machinery and equipment are used only for one activity and the depreciation expenses of them are attributed to relevant activity, except for ELV lift. 1 ELV depollution system and 1 ELV lift are used in depollution activity; 1 ELV lift (commonly used with depollution activity) and 1 dismantling tool are used in dismantling activity; 1 car baler is used in crushing/pressing activity and 1 forklift is used in transportation activity. Monthly depreciation expenses calculated based on registered values and economical lives of these machinery and equipment are provided in Table 1.

Table 1. Monthly Depreciation Expenses

\begin{tabular}{cc}
\hline Machinery and Equipments & Depreciation Expenses \\
\hline ELV Depollution System & $630 \mathrm{TL}$ \\
ELV Lift & $96 \mathrm{TL}$ \\
Dismantling Tools & $92 \mathrm{TL}$ \\
Car Baler & $942 \mathrm{TL}$ \\
Forklift & $833 \mathrm{TL}$ \\
\hline
\end{tabular}

Here, the costs to be attributed directly to the activities are taken into account as direct activity costs. Transportation cost (arising from transportation of hulks to shredders) is established as 60 TL per ELV. Monthly transportation costs are calculated as $275 \mathrm{ELV} \times 60 \mathrm{TL}=16.500 \mathrm{TL}$. Transportation cost can directly be attributed to transportation activity. The direct activity costs that are not subjected to allocation are shown in Table 2.

Table 2. Direct activity costs not subjected to allocation

\begin{tabular}{cc}
\hline Activities & Costs \\
\hline ELV acceptance and & $2.620 \mathrm{TL}$ \\
deregistration & - \\
Warehousing & $630 \mathrm{TL}$ \\
Depollution & $92 \mathrm{TL}$ \\
Dismantling & $942 \mathrm{TL}$ \\
Crushing & $17.333 \mathrm{TL}$ \\
Transportation
\end{tabular}




\section{The costs subjected to allocation;}

All activities are performed by 5 employees. One of these employees is located at ELV reception office. This employee also deals with the sale of the outputs. The cost associated with this employee is directly allocated to relevant activity. Another employee is working for testing and bar-coding of the outputs (C) to be sent to secondary market and the costs associated with this employee are assumed as direct labor cost of the relevant outputs. The remaining three employees are performing all the other activities. Therefore, labor costs of these three employees can not directly be attributed to the activities. In this cost item, the time spent by employee for each activity, in other words labor hours, is identified as the cost driver. Monthly cost of these three employees to the facility is $9.000 \mathrm{TL}$. The depreciation expense of machinery and equipment subjected to allocation is constituted only by ELV lift. This cost is allocated to depollution and dismantling activities since this machinery is being used commonly by two activities. Machine hours are considered as the cost driver. Monthly depreciated cost of ELV lift is 96 TL. Facility rent expense is also a common cost of the activities and the monthly amount is $2.500 \mathrm{TL}$. This cost item should be allocated based on the areas of the places in which the activities are implemented. In other words, the cost driver herein is the area required for performing the activities. Maintenance service is outsourced by the dismantler subject to this study. Monthly maintenance cost is $300 \mathrm{TL}$. This cost is also a common cost of the activities and the cost driver is determined as maintenance hours of the machines carrying out dismantling activities. Monthly total maintenance hours are established as 10 hours. Lastly, monthly electricity expenses are obtained as $1.200 \mathrm{TL}$. $\mathrm{kWh}$ consumed by the activities is taken as a cost driver. Monthly total electricity consumption for all activities is determined as 3.952 $\mathrm{kWh}$.

In the fourth step, the costs subjected to allocation are attributed to the activities (Fractions are attributed to the last activity):

The labor costs subjected to allocation is $9.000 \mathrm{TL}$ and labor hours spend for each activity is taken as a cost driver. Labor hours of activities and cost allocations are shown in Table 3. Labor cost per labor hour is calculated as $\cong 14,95 \mathrm{TL} /$ hour $(9.000 \mathrm{TL} / 602$ hours).

Table 3. Allocation of Labor Costs

\begin{tabular}{|c|c|c|c|c|c|}
\hline Activities & $\begin{array}{l}\text { Labor } \\
\text { Hours }\end{array}$ & & $\begin{array}{c}\text { Unit Labor } \\
\text { Cost }\end{array}$ & & $\begin{array}{c}\text { Activity Labor } \\
\text { Costs }\end{array}$ \\
\hline $\begin{array}{c}\text { ELV acceptance and } \\
\text { deregistration }\end{array}$ & - & & & & - \\
\hline Warehousing & - & & & & - \\
\hline Depollution & 135 hours & $\mathrm{x}$ & $14,95 \mathrm{TL} /$ hour & $=$ & $2.018 \mathrm{TL}$ \\
\hline Dismantling & 412 hours & $\mathrm{x}$ & $14,95 \mathrm{TL} /$ hour & $=$ & $6.159 \mathrm{TL}$ \\
\hline Crushing & 23 hours & $\mathrm{x}$ & $14,95 \mathrm{TL} / \mathrm{hour}$ & $=$ & $344 \mathrm{TL}$ \\
\hline Transportation & 32 hours & $\mathrm{x}$ & $14,95 \mathrm{TL} /$ hour & $=$ & $479 \mathrm{TL}$ \\
\hline
\end{tabular}

Machinery and equipment depreciation cost subjected to allocation is only arising for ELV lift. Since this machine is used commonly in depollution and dismantling activities, the cost is allocated to these two activities. Monthly depreciation cost is 96 
TL and machine hours are determined as a cost driver (Table 4). Depreciation cost per machine hour is calculated as $\cong 0,176 \mathrm{TL} /$ hours (96TL / 547 hours).

Table 4. Allocation of Machinery and Equipment Depreciation Costs

\begin{tabular}{|c|c|c|c|c|c|}
\hline Activities & $\begin{array}{l}\text { Machine } \\
\text { Hours }\end{array}$ & & $\begin{array}{c}\text { Unit } \\
\text { Depreciation } \\
\text { Cost } \\
\end{array}$ & & $\begin{array}{c}\text { Activity } \\
\text { Decpreciation } \\
\text { Costs } \\
\end{array}$ \\
\hline $\begin{array}{c}\text { ELV acceptance and } \\
\text { deregistration }\end{array}$ & - & & & & - \\
\hline Warehousing & - & & & & - \\
\hline Depollution & 135 hours & $\mathrm{x}$ & $0,176 \mathrm{TL} /$ hour & $=$ & $24 \mathrm{TL}$ \\
\hline Dismantling & 412 hours & $\mathrm{x}$ & $0,176 \mathrm{TL} /$ hour & $=$ & $72 \mathrm{TL}$ \\
\hline Crushing & - & & & & - \\
\hline Transportation & - & & & & - \\
\hline
\end{tabular}

The facility is not owned by the dismantler subject to our study and exploiter pays monthly $2.500 \mathrm{TL}$ for rent and facility has $315 \mathrm{~m}^{2}$ closed space. Areas where the activities are performed are established as a cost driver. Allocation of rent expenses to the activities is shown in Table 5. Rent cost per $\mathrm{m}^{2}$ is calculated as $\cong 7,94 \mathrm{TL} / \mathrm{m}^{2}($ $2.500 \mathrm{TL} / 315 \mathrm{~m}^{2}$ ).

Table 5. Allocation of rent expenses

\begin{tabular}{|c|c|c|c|c|c|}
\hline Activities & $\begin{array}{l}\text { Area } \\
\text { (m2) }\end{array}$ & & $\begin{array}{l}\text { Unit Rent } \\
\text { Cost }\end{array}$ & & $\begin{array}{c}\text { Activity } \\
\text { Rent Costs }\end{array}$ \\
\hline ELV acceptance and deregistration & $25 \mathrm{~m} 2$ & $\mathrm{x}$ & $7,94 \mathrm{TL} / \mathrm{m} 2$ & $=$ & $198 \mathrm{TL}$ \\
\hline Warehousing & $160 \mathrm{~m} 2$ & $\mathrm{x}$ & $7,94 \mathrm{TL} / \mathrm{m} 2$ & $=$ & $1.270 \mathrm{TL}$ \\
\hline Depollution & $50 \mathrm{~m} 2$ & $\mathrm{x}$ & $7,94 \mathrm{TL} / \mathrm{m} 2$ & $=$ & $397 \mathrm{TL}$ \\
\hline Dismantling & $50 \mathrm{~m} 2$ & $\mathrm{x}$ & $7,94 \mathrm{TL} / \mathrm{m} 2$ & $=$ & $397 \mathrm{TL}$ \\
\hline Crushing & $30 \mathrm{~m} 2$ & $\mathrm{x}$ & $7,94 \mathrm{TL} / \mathrm{m} 2$ & $=$ & $238 \mathrm{TL}$ \\
\hline Transportation & - & & & & - \\
\hline
\end{tabular}

For warehousing activity, $60 \mathrm{~m}^{2}$ is used for the storage of the outputs and $100 \mathrm{~m}^{2}$ is used for the storage of ELVs waiting to be processed. Here, cost allocation is made not only from the storage of the parts to be sold, but also the storage of ELVs. Monthly maintenance cost is established as 300TL and maintenance hours spent for the activities are taken as cost driver. Maintenance cost is not allocated to ELV acceptance and deregistration activity, warehousing activity and transportation activity. Activities, cost drivers and cost allocations are shown in Table 6. Maintenance cost per maintenance hour is calculated as $30 \mathrm{TL} / \mathrm{mh}(300 \mathrm{TL} / 10 \mathrm{mh})$. 
Table 6. Allocation of maintenance costs

\begin{tabular}{|c|c|c|c|c|c|}
\hline Activities & $\begin{array}{l}\text { Maintenance } \\
\text { Hours (mh) }\end{array}$ & & $\begin{array}{c}\text { Unit } \\
\text { Maintenance } \\
\text { Cost } \\
\end{array}$ & & $\begin{array}{c}\text { Activity } \\
\text { Maintenance } \\
\text { Costs } \\
\end{array}$ \\
\hline $\begin{array}{l}\text { ELV acceptance and } \\
\text { deregistration }\end{array}$ & - & & & & - \\
\hline Warehousing & - & & & & - \\
\hline Depollution & $2,5 \mathrm{mh}$ & $\mathrm{x}$ & $30 \mathrm{TL} / \mathrm{mh}$ & $=$ & $75 \mathrm{TL}$ \\
\hline Dismantling & $2,5 \mathrm{mh}$ & $\mathrm{x}$ & $30 \mathrm{TL} / \mathrm{mh}$ & $=$ & $75 \mathrm{TL}$ \\
\hline Crushing & $5 \mathrm{mh}$ & $\mathrm{x}$ & $30 \mathrm{TL} / \mathrm{mh}$ & $=$ & $150 \mathrm{TL}$ \\
\hline Transportation & - & & & & - \\
\hline
\end{tabular}

Monthly electricity cost is established as $1.200 \mathrm{TL}$ and $\mathrm{kWh}$ consumed by activities is considered as cost driver. Electricity cost is not allocated to warehousing and transportation activities. Allocation of electricity expenses to the relevant activities is given in Table 7. Electricity cost per $\mathrm{kWh}$ is calculated as $\cong 0,3036 \mathrm{TL} / \mathrm{kWh}(1.200 \mathrm{TL} /$ $3.952 \mathrm{kWh})$.

Table 7. Allocation of electricity costs

\begin{tabular}{ccccc}
\hline Activities & $\begin{array}{c}\text { KiloWat } \\
\text { t Hours } \\
\mathbf{( k W h})\end{array}$ & $\begin{array}{c}\text { Unit Electricity } \\
\text { Cost }\end{array}$ & $\begin{array}{c}\text { Activity } \\
\text { Electricity } \\
\text { Costs }\end{array}$ \\
\hline $\begin{array}{c}\text { ELV acceptance and } \\
\text { deregistration }\end{array}$ & $52 \mathrm{kWh}$ & $\mathrm{x}$ & $0,3036 \mathrm{TL} / \mathrm{kWh}$ & $=16 \mathrm{TL}$ \\
Warehousing & - & & & - \\
Depollution & $520 \mathrm{kWh}$ & $\mathrm{x}$ & $0,3036 \mathrm{TL} / \mathrm{kWh}=$ & $158 \mathrm{TL}$ \\
Dismantling & $780 \mathrm{kWh}$ & $\mathrm{x}$ & $0,3036 \mathrm{TL} / \mathrm{kWh}=$ & $237 \mathrm{TL}$ \\
Crushing & 2.600 & $\mathrm{k}$ & $0,3036 \mathrm{TL} / \mathrm{kWh}$ & $=789 \mathrm{TL}$ \\
Transportation & - & & & - \\
\hline
\end{tabular}

Distribution of indirect costs and direct and indirect cost shares of general production costs for activities are shown in Figures 4-5. Figure 4 shows that the most of the labor costs is arising from dismantling activity since it is a labor-intensive process. Dismantling activity is followed by depollution in terms of generating labor cost. Electricity cost is arising from the crushing, dismantling, depollution, and ELV acceptance and deregistration activities, when ordered from highest to lowest. Another result that can be reached from the Figure 4 is that a large part of the rent expenditure is arisen from the warehousing activity. On the other hand, the most of the direct costs is arising from transportation activity, whereas the dismantling activity constitutes the most of the indirect costs (Figure 5). 


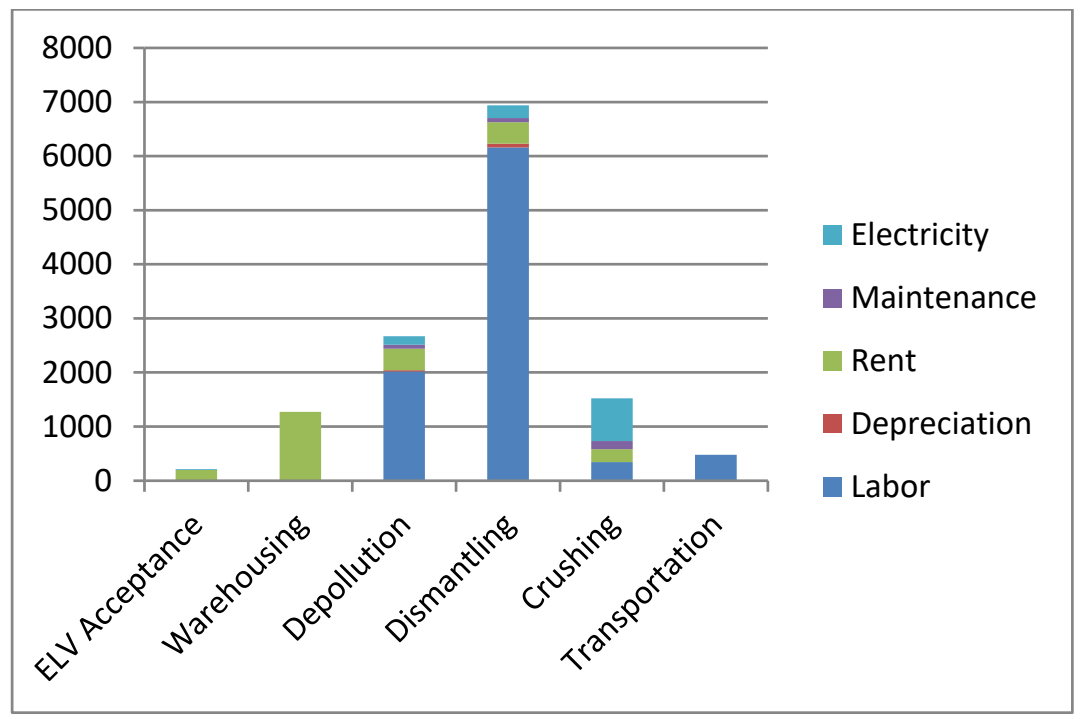

Figure 4. Indirect costs of activities

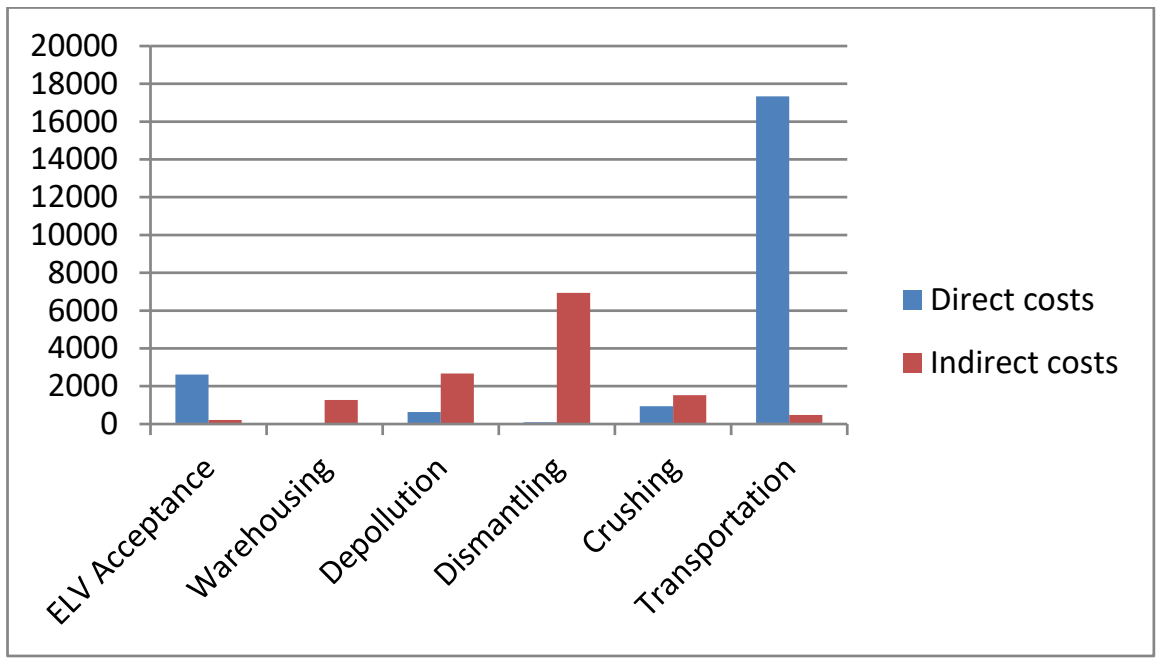

Figure 5. Direct and indirect costs of activities

Following the cost allocation of the activities, the costs subjected to allocation and the costs not subjected to allocation are added and total costs of the activities are obtained (Table 8).

Table 8. Total Costs

\begin{tabular}{cc}
\hline Activities & Activity Total Cost (TL) \\
\hline ELV acceptance and deregistration & $2.834 \mathrm{TL}$ \\
Warehousing & $1.270 \mathrm{TL}$ \\
Depollution & $3.302 \mathrm{TL}$ \\
Dismantling & $7.032 \mathrm{TL}$ \\
Crushing & $2.463 \mathrm{TL}$ \\
Transportation & $17.812 \mathrm{TL}$ \\
Total Cost & $34.713 \mathrm{TL}$ \\
\hline
\end{tabular}

In the fifth step, cost pools are constituted. Homogeneity should be taken into consideration while forming the cost pools. Homogeneous cost pools consist of bringing 
the activity costs that are directly related to products together. Here in this case, warehousing and transportation activities are aggregated in a single cost pool. A separate cost pool is constituted for each one of the other activities. The information about the costs aggregated in cost pools is given in Table 9 .

Table 9. Aggregated costs in cost pools

\begin{tabular}{cc}
\hline Cost Pools & Total Cost (TL) \\
\hline $\begin{array}{c}\text { Cost Pool 1 } \\
\text { (ELV acceptance and deregistration) } \\
\text { Cost Pool 2 }\end{array}$ & $2.834 \mathrm{TL}$ \\
(Warehousing and Transportation) & $19.082 \mathrm{TL}$ \\
$\quad \begin{array}{c}\text { Cost Pool 3 } \\
\text { (Depollution) } \\
\text { Cost Pool 4 } \\
\text { (Dismantling) } \\
\text { Cost Pool 5 } \\
\text { (Crushing/Pressing) } \\
\text { Total Cost }\end{array}$ & $3.302 \mathrm{TL}$ \\
& $7.032 \mathrm{TL}$ \\
\end{tabular}

In the sixth step, the relationships between the activities and outputs are established. In other words, cost drivers are determined. By the help of cost drivers, cost allocation to the outputs will be performed. While identifying the cost drivers, it is quite significant that they should be able to determine activity consumption of the outputs. A single cost driver is identified for each cost pool and then allocation ratios of cost pools are calculated through dividing the costs in each cost pool by the value of relevant cost driver (Table 10).

Table 10. Allocation ratios

\begin{tabular}{ccc}
\hline Cost Pool & Cost Driver & $\begin{array}{c}\text { Cost Pool Allocation } \\
\text { Ratio }\end{array}$ \\
\hline 1 & Number of ELVs accepted & $10,31 \mathrm{TL} / \mathrm{ELV}$ \\
2 & (Equal Allocation) & $0,0694 \mathrm{TL} / \mathrm{kg}$ \\
3 & Weight & $24,46 \mathrm{TL} / \mathrm{hour}$ \\
4 & Depollution duration & $17,07 \mathrm{TL} / \mathrm{hour}$ \\
5 & Dismantling duration & - \\
\hline
\end{tabular}

Since only the output group (B) to be sent to shredder is benefiting from the cost pool 5 , the costs in this cost pool are not allocated to outputs and thus allocation ratio is not calculated.

In the seventh step, costs are allocated to outputs through the allocation ratios of the cost pools (Table 11). Here, cost driver consumptions of the outputs are taken into consideration. With this step, allocation of general production costs to output groups is completed (Fractions were allocated to the last output (C) group).

Cost allocation is performed from the cost pools to the outputs. From these data, general production costs of each output are calculated and given in Table 12. 
Table 11. Cost allocation to the outputs from the cost pools

\begin{tabular}{|c|c|c|c|c|c|c|}
\hline $\begin{array}{l}\text { Costing } \\
\text { Pool }\end{array}$ & Outputs & Allocation Ratio & & $\begin{array}{c}\text { Number of ELVs } \\
\text { Accepted (Equal } \\
\text { Allocation) }\end{array}$ & & $\begin{array}{l}\text { Cost Allocated to } \\
\text { the Outputs from } \\
\text { the Cost Pool } 1\end{array}$ \\
\hline \multirow{4}{*}{1} & $\mathrm{~A}$ & $10,31 \mathrm{TL} / \mathrm{ELV}$ & $\mathrm{x}$ & $91,67 \mathrm{ELV}$ & $=$ & $945 \mathrm{TL}$ \\
\hline & $\mathrm{B}$ & 10,31 TL/ELV & $\mathrm{x}$ & 91,67 ELV & $=$ & $945 \mathrm{TL}$ \\
\hline & $\mathrm{C}$ & $10,31 \mathrm{TL} / \mathrm{ELV}$ & $\mathrm{x}$ & 91,67 ELV & $=$ & $944 \mathrm{TL}$ \\
\hline & Outputs & Allocation Ratio & & Output Weights (kg) & & $\begin{array}{l}\text { Cost Allocated to } \\
\text { the Outputs from } \\
\text { the Cost Pool } 2\end{array}$ \\
\hline \multirow{4}{*}{2} & A & $0,0694 \mathrm{TL} / \mathrm{kg}$ & $\mathrm{x}$ & $14.850 \mathrm{~kg}$ & $=$ & $1.031 \mathrm{TL}$ \\
\hline & B & $0,0694 \mathrm{TL} / \mathrm{kg}$ & $\mathrm{x}$ & $222.750 \mathrm{~kg}$ & $=$ & $15.459 \mathrm{TL}$ \\
\hline & $\mathrm{C}$ & $0,0694 \mathrm{TL} / \mathrm{kg}$ & $\mathrm{x}$ & $37.400 \mathrm{~kg}$ & $=$ & $2.592 \mathrm{TL}$ \\
\hline & Outputs & Allocation Ratio & & $\begin{array}{l}\text { Depollution Duration } \\
\text { (hours) }\end{array}$ & & $\begin{array}{l}\text { Cost Allocated to } \\
\text { the Outputs from } \\
\text { the Cost Pool } 3\end{array}$ \\
\hline \multirow{4}{*}{3} & A & 24,46 TL/hour & $\mathrm{x}$ & 35 hour & $=$ & $856 \mathrm{TL}$ \\
\hline & B & 24,46 TL/hour & $\mathrm{x}$ & 30 hour & $=$ & $734 \mathrm{TL}$ \\
\hline & $\mathrm{C}$ & 24,46 TL/hour & $\mathrm{x}$ & 70 hour & $=$ & $1.712 \mathrm{TL}$ \\
\hline & Outputs & Allocation Ratio & & $\begin{array}{c}\text { Dismantling Duration } \\
\text { (hours) }\end{array}$ & & $\begin{array}{l}\text { Cost Allocated to } \\
\text { the Outputs from } \\
\text { the Cost Pool } 4\end{array}$ \\
\hline \multirow{3}{*}{4} & $\mathrm{~A}$ & 17,07 TL/hour & $\mathrm{x}$ & 103 hour & $=$ & $1.758 \mathrm{TL}$ \\
\hline & $\mathrm{B}$ & 17,07 TL/hour & $\mathrm{x}$ & - & $=$ & - \\
\hline & $\mathrm{C}$ & 17,07 TL/hour & $\mathrm{x}$ & 309 hour & $=$ & $5.274 \mathrm{TL}$ \\
\hline
\end{tabular}

Table 12. General production costs of the outputs

\begin{tabular}{cc}
\hline Outputs & General Production Cost \\
\hline A & $4.590 \mathrm{TL}$ \\
B & $19.601 \mathrm{TL}$ \\
C & $10.522 \mathrm{TL}$ \\
Total & $34.713 \mathrm{TL}$ \\
\hline
\end{tabular}

After completing the allocation of general production costs to the outputs for a monthly period, total costs of each output group are calculated and results are shown in Table 13.

Table 13. Total Output Costs

\begin{tabular}{ccccc}
\hline Outputs & $\begin{array}{c}\text { Direct Raw } \\
\text { Material and } \\
\text { Supply Cost }\end{array}$ & $\begin{array}{c}\text { Direct Labor } \\
\text { Cost }\end{array}$ & $\begin{array}{c}\text { General } \\
\text { Production } \\
\text { Cost }\end{array}$ & Total Costs \\
\hline A & - & - & $4.590 \mathrm{TL}$ & $4.590 \mathrm{TL}$ \\
$\mathrm{B}$ & - & - & $19.601 \mathrm{TL}$ & $19.601 \mathrm{TL}$ \\
$\mathrm{C}$ & - & $2.500 \mathrm{TL}$ & $10.522 \mathrm{TL}$ & $13.022 \mathrm{TL}$ \\
\hline
\end{tabular}

The eight and the last step includes the formulation of the reports. In conclusion, firstly we determined the direct costs of ELV processing in a dismantler that can be associated with activities directly. Then, indirect costs of ELV processing for which 
directly association with activities is not possible were determined and attributed to activities by using cost drivers. Total activity costs were obtained by accumulating direct and non-direct costs for each activity. In the next stage, we tried to identify how much each output consumes this activity by relating these costs with outputs of ELV treatment process. The results of the application of ABC framework to a dismantler's ELV recovery activities show that, remaining part of ELV after depollution and dismantling processes which is called as "hulk" has a maximum share in the total expenses of the firm, whereas, group A output which is consisting of big vehicle components composed of recyclable materials, fluids, tire, etc. and to be forwarded to recyclers has minimum. The reason is that hulk constitutes the heaviest part of the ELV (about $810 \mathrm{~kg}$ in a $1000 \mathrm{~kg} \operatorname{ELV}(\mathrm{GHK}, 2006)$ ) and firm is bearing the transportation expenses of hulks to the shredders. When considering the revenue obtained from the sale of hulks to shredders, the firm reported that the cost of group B output is acceptable (revenue obtained from selling hulk is averagely 50-100\$/ELV in European countries). Firm also reported that the most profitable output group is $\mathrm{C}$ sold to secondary markets.

The results of the study show that indirect costs have a substantial share in the total costs of the firm. We obtain a precise enough cost results for effective decision making of dismantler, which is not possible with traditional costing systems since it is attributing costs to products with volume-based manner. We believe that the step by step $\mathrm{ABC}$ processing model can be guide for other companies practicing reverse logistics activities in terms of understanding and managing the reverse logistics costs.

\section{Conclusion}

Although the share of logistics costs in total operating costs varies from sector to sector and from firm to firm, logistics costs have been increasing from past to present with the increasing customer expectations. Proper management of logistics activities is a necessity for enterprises in the emerging global market in terms of both increasing costs and customer service levels. Although its necessity, costing and performance measuring of logistics processes with $\mathrm{ABC}$ is not a common occurrence both in the practice and literature since it is not well understood. In fact, traditional cost accounting is inadequate to identify the logistics costs truly, since it is considering logistics as part of sales, general, and administrative expenses.

Another challenge faced by enterprises is that taking the responsibility of reverse flows of their products in today's business world. There are legislations encumbering manufacturers to incorporate environmental factors into their decisions in several industries. Although, reverse logistics activities are being implemented increasingly in several sectors such as electrical and electronic equipments, battery and accumulators, automobiles, tires, packages, etc. to get economic and ecological benefits, and to cope with legislations, research is lacking on how to manage the reverse logistics activities and their costs efficiently. $\mathrm{ABC}$ is a pat method to identify the reverse logistics activities of firms which are being performed to get remaining value of returned products for economic goals and/or to reach the targets obliged by legislations. Owing to well recognized resources and activities consuming them; more precise cost information of treated materials obtained from reverse logistics activities can be achieved by implementation of ABC.

In this paper, a reverse logistics costing framework integrated with $\mathrm{ABC}$ model is developed with the aim of helping managers improve the understanding and managing 
of reverse logistics costs. Model is illustrated on an example of a licensed firm in Turkey that dismantles the ELVs according the standards identified in ELVs regulation. The most important reason for applying $\mathrm{ABC}$ model to determine the reverse logistics costs of a dismantler is that a large number of activities carried out in the treatment process of ELVs and the direct relationship between these activities and costs. In this study, it is assumed that manufacturers don't pay fee to returned ELVs from consumers, so there is no direct raw material cost. Direct relationship between the labor costs and the activities is established only between $\mathrm{C}$ group output to be sent to secondary markets and testing and bar-coding activity. Other labor costs, depreciation costs of commonly used machinery, rent expenses of the facility, maintenance costs, and electricity costs are established as costs subjected to allocation. These costs are attributed to the activities. Then total costs of activities (direct and indirect) are determined. Transportation activity is established as the most costly activity in this step. In order to transform the activity costs to output costs, homogeneous cost pools are formed with the aim of expressing each one with a single cost driver. Five cost pools are constituted and cost drivers are established that identify the activity consumption of the outputs of the firm. And lastly, costs are allocated to outputs through allocation ratios of the cost pools. Outputs of a dismantler subject to this study are sorted in three groups as Group A including the parts/components sold to recycler, Group B including the hulk sold to shredder, and Group $\mathrm{C}$ including the parts/components sold to secondary markets. The precise costs of these outputs to the firm are determined separately and the profitability of different output groups are discussed. According to general production costs and also total costs sharing, the highest share is observed for Group B and the least share is observed for Group A.

The model in this paper can be applied to other reverse logistics practices that are mentioned above which is not limited to ELV recycling. Since a better cost estimation is of significant importance also for some other decision making problems like network design and distribution, obtained results can be used as inputs of reverse logistics network design/re-design problems for efficient design and optimal solutions. The limitations and shortcomings of the paper can be stated as; there is not a comparison of costs obtained by ABC with traditional costing results since firm doesn't trace its costs by using a traditional system or other methods. In addition, the results will expired by selecting different cost drivers in the analyzed firm.

Since reverse logistics activities are encouraged by different drivers such as economic and environmental benefits, obligations by governments and social responsibilities, evaluation of activities and outputs will be handled in terms of costs and environmental effects simultaneously as a future research. And also different costing approaches will be performed to reverse logistics systems such as kaizen costing, target costing and comparison of these methods with $\mathrm{ABC}$ will be studied in the future. 


\section{References}

Al-Omiri, M.; Drury C. (2007). Organizational and behavioral factors influencing the adoption and success of ABC in the UK. Cost Manag, 21, 38.

Arslan, S.; Varol N.B. (2010). Storage costs in respect to activity-based cost on the logistics chain and a case study. Account Auditing Rev, 69-88.

Askarany, D.; Yazdifar, H.; Askary, S. (2010). Supply chain management, activitybased costing and organisational factors. Int J Prod Econ, 127 (2010): 238-248.

Askarany, D.; Yazdifar, H.; Askary, S. (2012). An investigation into the mixed reported adoption rates for $\mathrm{ABC}$ : Evidence from Australia, New Zealand and the UK. Int J Prod Econ, 135 (1): 430-439.

Baykasoğlu, A.; Kaplanoğlu, V. (2008). Application of activity-based costing to a land transportation company: A case study. Int J Prod Econ, 116 (2): 308-324.

Bras, B.; Emblemsvag J. (1995). The use of activity-based costing, uncertainty, and disassembly action charts in demanufacture cost assessments. 1995 ASME Advances in Design Automation Conference, Boston, Massachusetts, September, 17-20.

Brierley, J.A.; Cowton, C.J.; Drury, C. A (2006). Comparison of product costing practices in discrete-part and assembly manufacturing and continuous production process manufacturing. Int J Prod Econ, 100: 314-321.

Chen, F.F. (1996). Activity-Based Approach to Justification of Advanced Factory Management Systems. Ind Man Data Sys, 96 (2): 17-27.

Chileshe, N.; Rameezdeen, R.; Hosseini, M.R. (2016). Drivers for adopting reverse logistics in the construction industry: a qualitative study. Eng Constr Archit Manag, 23 (2): 134-157.

Chileshe, N.; Rameezdeen, R.; Hosseini, M.R.; Lehmann, S.; Udeaja, C. (2016). Analysis of reverse logistics implementation practices by South Australian construction organizations. Int J Oper Prod Manag, 36 (3): 332-356.

Coates, G.; Rahimifard, S. A cost estimation framework to support increased value recovery from end-of-life vehicles. Int J Comput Integr Manuf, 2008, 21 (8): 895-910.

Dekker, H.C.; van Goor, A.R. (2000). Supply chain management and management accounting: a case study of activity based costing. Int J Logist: Res Appl, 3(1): $41-52$.

Deran, A.; Arslan, S.; Köksal, A.G. İşletmelerde Lojistik Maliyetlerin Hesaplanması. Eğitim Press, Konya, Turkey.

Demirel, E.; Demirel, N.; Gökçen, H. (2016). A mixed integer linear programming model to optimize reverse logistics activities of end-of-life vehicles in Turkey. J Clean Prod, 112(3): 2101-2113.

Demirel, N.Ö.; Gökçen, H. (2008). A mixed integer programming model for remanufacturing in reverse logistics environment. Int J Adv Manuf Technol, 39 (11-12): 1197-1206.

Directive 2000/53/EC, Available online: http://eurlex.europa.eu/LexUriServ/LexUriServ.do?uri=CONSLEG:2000L0053: 20050701:EN:PDF, (Accessed on 20 December 2017). 
Doğan, A. (1996). Activity based costing system: Structure, Differences and costing process. Çukurova Univ Fac Econ Adm Sci, 6(1): 207-228.

Fleischmann, M.; Beullens, P.; Bloemhof-Ruwaard, J.M.; van Wassenhove, L.N. (2001). The impact of product recovery on logistics network design. Prod Oper Manag, 10(2): 156-173.

GHK, (2006). A study to examine the benefits of the End of Life Vehicles Directive and the costs and benefits of a revision of the 2015 targets for recycling, re-use and recovery under the ELV Directive, Final report to DG Environment, Birmingham, USA, 2006.

Goldsby, T.J.; Closs, D.J. (2000). Using activity-based costing to reengineer the reverse logistics channel. Int J Physl Distrib Logist Manag, 30(6): 500-514.

Hao, H; Zhang, Q.; Wang, Z; Zhang, J. (2018). Forecasting the number of end-of-life vehicles using a hybrid model based on grey model and artificial neural network. J Clean Prod, 2018, 202,684-696.

Hilton, R.W. (2005). Managerial accounting. New York, McGraw-Hill.

Huang, X.X.; Newness, L.B.; Parry, G.C. (2012). The adaptation of product cost estimation techniques to estimate the cost of service. Int J Comput Integr Manuf, 25(4-5): 417-431.

https://izinlisans.cevre.gov.tr/Sorgular/YazilimNetIzinLisansSorgula.aspx, Turkish Republic Ministry of Environment and Urbanization, (Accessed on 10 January 2018).

https://www.gov.uk/government/uploads/system/uploads/attachment_data/file/31736/11 -528-depolluting-end-of-life-vehicles-guidance.pdf, Depolluting End-of-Life Vehicles (cars and light goods vehicles) Guidance for Authorised Treatment Facilities, (Accessed 13 December 2017).

Karğın, S. (2013). Rise And Fall Of Activity Based Costing Method. MUFAD J, 2013, 58: 21-40.

Khan, S.A.R.; Dong, Q.L.; Yu, Z.; Khan, S.S. (2017). Research on Decision-making of Green Reverse Logistics in Enterprises: A Case Study on Electronic Products Manufacturers from the Perspective of South Africa. 2017 2nd International Conference on Advances in Management Engineering and Information Technology AMEIT 2017: 11-18.

Krajnc, J.; Logozar, K.; Korosec, B. (2012). Activity-based management of logistic costs in a manufacturing company: A Case of Increased Visibility of Logistic Costs in a Slovenian Paper Manufacturing Company. Traffic and Transp, 2012, 24(1): 15-24.

LaLonde, B.J.; Pohlen, T.L. (1996). Issues in supply chain costing. Int J Logist Manag, 1996, 7(1): 1-12.

Lin, B.; Collins, J.; Su, R.K. (2001). Supply chain costing: an activity-based perspective. Int J Physl Distrib Logist Manag, 2001, 31(10): 702-713.

Lin, Y.; Jia, H.; Yang, Y.; Tian, G.; Tao, F.; Ling, L. (2018). An improved artificial bee colony for facility location allocation problem of end-of-life vehicles recovery network. J Clean Prod, 2018, 205 (2018): 134-144.

Liu, J.M. (2006). End-of-life vehicle recycling and disassembly technique. Chemical Industry Press, Beijing in Chinese, 2006. 
Mohan, C.J.B. (2013). The Impact of Logistic Management on Global Competitiveness. Int Jof Bus Manag Invent, 2013, 2(3): 39-42.

Özceylan, E.; Demirel, N.; Çetinkaya, C.; Demirel, E. (2017). A closed-loop supply chain network design for automotive industry in Turkey. Comput Ind Eng, 2017, 113(2017): 727-745.

Özdemir, E.; Kaygusuz, S.Y. (2009). Customer profitability analysis: measuring with activity-based costing and using customer profitability analysis in marketing decisions. "Is, Guc" Ind Relat Hum Resour J, 2009, 11(3): 87-112.

Özkan, A.; Aksoylu, S. (2002). Integrated Implementation of Kaizen and Activity Based Costing. MODAV World Acc Sci, 2002, 4(3): 49-63.

Peretti, U.; Tatham, P.; Wu, Y; Sgarbossa, F. (2015). Reverse logistics in humanitarian operations: challenges and opportunities. J Hum Logist Supply Chain Manag, 2015, 5 (2), 253-274.

Pirttilä, T.; Hautaniemi, P. (1995). Activity-based Costing and Distribution Logistics Management. Int J Prod Econ, 1995, 41(1-3): 327-333.

Pohlen, T.; Coleman, B.J. (2005). Evaluating internal operations and supply chain performance using EVA and ABC, SAM Adv Manag J, 2005, 70(2): 45-58.

Rajeshkumar. B.C.; RameshBabu, T. (2006). Evaluation of logistics related policies between two different levels of the supply chain network - a case study. Ann Op Res, 2006, 143: 77-89.

Schulze, M.; Seuring, S.; Ewering, C.(2012). Applying activity-based costing in a supply chain environment. Int J Prod Econ, 2012, 135 (2012): 716-725.

Seuring, S. Supply chain costing - a conceptual framework in: Seuring S, Goldbach M(Eds.), Cost Management in Supply Chains, Heidelberg, 16-30, 2000.

Shibi, A.; Eglese, R.W. (2010). Combinatorial optimization and Green Logistics. Ann Op Res, 2010, 175: 159-175.

Stapleton, D.; Pati, S.; Beach, E.; Julmanichoti, P. (2004). Activity-based costing for logistics and marketing. Bus Process Manag J, 2004, 10(5): 584-597.

Şen, İ.K. (2014). Management of Logistics Activities and Costing Approaches. Çankırı Karatekin Univ J Fac Econ and Adm Sci, 2014, 4(1): 83-106.

Tsai, W.H.; Hung, S.J. (2009). A fuzzy goal programming approach for green supply chain optimisation under activity-based costing and performance evaluation with a value-chain structure. Int J Prod Res, 2009, 47(18): 4991-5017.

Wang, G.; Gao, Z.; Lin, T.W. (2010). Using ABC to Improve the Logistics Value Chain in a Chinese Food Product Company. Cost Manag, 2010, 24(1): 39-46.

Xia, X.; Li, J.; Tian, H.; Zhou, Z.; Li. H.; Tian, G.; Chu, J. (2016). The construction and cost-benefit analysis of end-of-life vehicle disassembly plant: a typical case in China. Clean Technol Environ Policy, 2016, 18(8): 2663-2675.

Zhongdong, X.; Jianan, S.; Wenjun, S.; Tianwei, W. (2018). Location-allocation problem of reverse logistics for end-of-life vehicles based on the measurement of carbon emissions. Comput Ind Eng, https://doi.org/10.1016/j.cie.2018.12.012. 